\title{
Analysis of The Relationship Between Smoking and Chronic Respiratory Symptoms, Level of Income and Education
}

\section{Sigara Kullanımı ile Kronik Solunumsal Semptomlar, Gelir Seviyesi ve Eğitim Düzeyi Arasındaki İlişkinin Analizi}

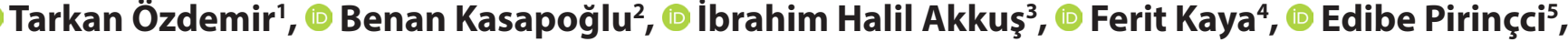 \\ Semiha Eren ${ }^{6}$, @ Mustafa Hamidullah Türkkanı ${ }^{7}$, @ Çiğdem Özdilekcan', ๑ Irem Bulut ${ }^{6}$
}

\author{
'University of Health Sciences Dr. Abdurrahman Yurtaslan Oncology Education and Research Hospital Department of Pulmonology, Ankara, Turkey \\ ${ }^{2}$ University of Health Sciences Dr. Abdurrahman Yurtaslan Oncology Education and Research Hospital Department of Internal Medicine, Ankara, Turkey \\ ${ }^{3}$ Public Health Directorate Department of Family Medicine, Elazığ, Turkey \\ ${ }^{4}$ Adıyaman Education and Research Hospital Department of Public Health, Adıyaman, Turkey \\ ${ }^{5}$ Fırat University Department of Public Health, Elazığ, Turkey \\ ${ }^{6}$ Public Health Directorate Department of Health Management, Elazığ, Turkey \\ ${ }^{7}$ Sincan State Hospital Department of Pulmonology, Ankara, Turkey
}

\begin{abstract}
Objective: In this study, we aimed to determine the general demographic characteristics of smokers and to define the association of smoking with respiratory symptoms, level of education and income.

Material and Method: This prospective study was conducted on 1019 people aged 40 and over. A questionnaire containing questions about respiratory symptoms, tobacco use and risk factors for chronic respiratory diseases was applied to all the participants. The study participants were grouped regarding their smoking status as current smokers, never smokers and former smokers. Age, gender, marital status, education level, monthly income per house person were recorded for all participants.

Results: 1019 people with a mean age of $53.20 \pm 9.06$ years (range: 40-90 years) were included in the study. Among females, 72/486 were active smoker; while in males $226 / 533$ were active smoker (p:0.001). Midhigh school and university graduates were more commonly smoker or former-smoker. Participants with higher monthly income per house person (> 1000 TRY) were significantly more commonly active-smoker. Cough and sputum for longer than 3 months was determined in $66(6.5 \%)$ people while the triad of cough and sputum for longer than 3 months and dyspnea was determined in $36(3.5 \%)$ people. Among those participants the ratio of smokers was significantly higher. A significant proportion of participants $(63.8 \%)$ with the symptoms predicting chronic pulmonary diseases, were not having diagnosis of any chronic respiratory disease before.

Conclusion: We determined that; unlike the previous reports educated and higher monthly income people were more commonly smoker. We also found that chronic respiratory diseases is not sufficiently diagnosed. In screening for early diagnosis of chronic pulmonary diseases, we think that symptomatic interrogation is still important for selection of target population.

Keywords: Chronic pulmonary diseases; tobacco use; sociocultural situation; early diagnosis
\end{abstract}

Öz

Amaç: Bu çalışmada sigara içenlerin genel demografik karakterlerini belirlemeyi ve sigara içme ile solunumsal belirtiler, eğitim ve gelir düzeyi arasındaki ilişkiyi tanımlamayı amaçladık.

Gereç ve Yöntem: 40 yaş ve üzeri 1019 kişinin dahil edildiği prospektif bir çalışma planlandı. Tüm katılımcılara solunumsal belirtiler, tütün kullanımı ve kronik solunum hastalığı ile ilişkili risk faktörlerini sorgulayan bir anket yapıldı. Çalışma katıımcıları sigara içme durumlarına göre halen içenler, hiç içmeyenler ve sigarayı bırakmış olanlar şeklinde gruplandırıldı.Yaş, cinsiyet, evlilik durumu, eğitim seviyesi ve kişi başı aylık gelir düzeyi tüm katılımcılar için kaydedildi.

Bulgular: Ortalama yaşı 53.20 ×9.06 (range: 40-90 yıl) olan 1019 kiși çalışmaya dahil edildi. Kadınlar arasında 72/486 erkekler arasında 226/533 kişi aktif sigara içicisiydi (p:0.001). Orta okul-lise ve üniversite mezunları daha fazla sıklıkla sigara içiyor veya sigarayı bırakmıştı. 3 aydan daha uzun süren öksürük ve balgam katılımcıların 66'sında (\%6.5) tespit edilmişken, 3 aydan uzun süren öksürük, balgam, nefes darlığı bir triad olarak katılımcıların 36'sında (\%3.5) tespit edildi. Bu hasta gurupları arasında sigara kullananların oranı belirgin olarak yüksekti. Kronik akciğer hastalığı düşündüren semptomları olan hastaların önemli bir kısmının (\% 63.8) daha önce herhangi bir kronik solunum hastalığı tanısı yoktu.

Sonuç: Önceki raporların aksine, eğitimli ve daha yüksek aylık gelirlilerde daha fazla sigara içildiğini tespit ettik. Ayrıca kronik solunumsal hastalıklarının yeterince teşhis edilemediğini bulduk Kronik akciğer hastalıklarının erken teşhisi için yapılacak taramalarda hedef populasyonun seçimi için semptomatik sorgulamanın halen önemli olduğunu düşünüyoruz.

Anahtar Kelimeler: Kronik akciğer hastalığı; tütün kullanımı; sosyokültürel durum; erken tanı 


\section{INTRODUCTION}

Smoking is one of the major public health problems causing several heart and lung diseases. ${ }^{[1]}$ The relationship between smoking and chronic obstructive pulmonary disease (COPD) has clearly been shown before. ${ }^{[2]}$ In some countries in the world with high smoking prevalence, smoking was attributed to $25 \%$ of all deaths among young and middle aged people. ${ }^{[3,4]}$ Prevention of smoking or encouraging smoking cessation is the main treatment methods of smoking. ${ }^{[5]}$

Chronic obstructive pulmonary disease is still one of the main causes of morbidity and mortality in all over the world. ${ }^{\left[{ }^{[6]}\right.}$

Despite recent advances in awareness and diagnostic methods in COPD, there is still a high prevalence of undiagnosed COPD patients. The symptomatology of COPD is important for early diagnosis. In that aspect, chronic cough, dyspnea (breathlessness) and chronic sputum were shown to be important predictors of COPD. ${ }^{[7,8]}$

Although the association of COPD with smoking is obviously known, the exact number of patients with COPD symptoms among smokers is not defined since there is still an important ratio of undiagnosed COPD patients.

It is important to determine the general characteristics of smokers and their association with respiratory symptoms especially for the construction of strategies to stop this mortal habit especially in words of public health. Moreover presence of COPD symptoms may also elucidate the exact association of COPD with smoking even in early periods of COPD.

In this study, we aimed to determine the general demographic characteristics of smokers and to define the association of smoking with respiratory symptoms among people living in Elazığ, Turkey.

\section{MATERIAL AND METHOD}

The study was performed in Elazığ between April 2016 and September 2016. The study was approved by local ethics committee. Informed consent was obtained from all participants. This study was applied to people aged 40 and over in Elazığ province. The population of people aged 40 and over registered in Elazığ Family Medicine departments was 178038 at that time and constituted the universe of the study. The formula $\mathrm{n}=\mathrm{Nt} 2 \mathrm{pq} / \mathrm{d} 2(\mathrm{~N}-1)+\mathrm{t} 2 \mathrm{pq}$ was used to determine the sample group. $95 \%$ confidence interval, $12.5 \%$ prevalence and $2 \%$ deviation were used for sampling.

The number of people in the sample group was calculated as 1050. People aged 40 and over were selected randomly from the list registered to the family health unit. The criterion for inclusion in the study group was 40 years of age and over. The exclusion criteria were to have a physical or mental disease that cannot be cooperated, to have an auditor, visual or cognitive dysfunction that prevent communication, not to accept the interview. 31 people were excluded due to the exclusion criteria. A questionnaire was applied to the participants. The questionnaire was prepared with the guidance of the previous literature by the researchers. Since this is not a scale study, the validity and reliability of the questions were not performed. The questionnaire was applied by health professionals who have received the necessary training and the survey will be carried out face to face. The questionnaires were pre-applied on the group of 20 people before they were applied to the sampling recipients and necessary corrections were made. The questionnaire contains questions about respiratory symptoms, tobacco use and risk factors for COPD. Totally 1019 participants were included in the study and the study participants were grouped regarding their smoking status as current smokers (n:298), never smokers (n:516) and former smokers (n:205). Age, gender, weight, height, marital status, education level, number of household people, monthly income per house person were all recorded. In the level of education, the definition of primary school refers to the first five years of education and the definition of midhigh school refers to 6 years of education in addition to the primary school. The study participants were also asked for the presence of respiratory symptoms such as cough, sputum, effort or effortless dyspnea; and previous diagnoses of chronic pulmonary disease, and medications.

\section{Statistical analysis}

Statistical analysis was performed using the statistical package for the social sciences (SPSS) version 21 (SPSS Inc., Chicago, IL, USA). Continuous variables are presented as mean \pm standard deviation and categorical data are presented as a number or frequencies when appropriate. Comparison of quantitative variables between the study groups was performed using one-way analysis of variance for comparing three groups. For comparing categorical data, Chi-square $(x 2)$ test was performed and Fisher's exact test was used when appropriate. $p<0.05$ was considered statistically significant.

\section{RESULTS}

Totally 1019 participants (486 female, 533 male) with a mean age of $53.20 \pm 9.06$ years (range: $40-90$ years) were included in the study. Among study participants, $29.2 \%$ were activesmoker while $20.1 \%$ were former-smoker. Demographic features of study participants are summarized in Table 1. Regarding these findings, males were more commonly active-smoker or former-smoker compared with the females $(p: 0.001)$. Among females, $72 / 486$ (14.8\%) were activesmoker; while in males 226/533 (42.4\%) were active-smoker. Regarding the educational status, uneducated participants or primary school graduates were non-smoker; while mid-high school and university graduates were more commonly activesmoker or former-smoker. Participants with higher monthly income per house person (>1000 TRY) were significantly more commonly active-smoker and participants living with more than 5 people at home were more commonly active-smoker. Pulmonary symptoms of study participants were recorded. Regarding these findings, prolonged cough for more than 3 months was more common in active-smoker and formersmoker. Similarly prolonged sputum was also more common in active-smoker and ex-smoker. 


\begin{tabular}{|c|c|c|c|c|}
\hline & $\begin{array}{l}\text { Active- } \\
\text { smoker } \\
\text { (n:298) }\end{array}$ & $\begin{array}{c}\text { Non-smoker } \\
(n: 516)\end{array}$ & $\begin{array}{l}\text { Former- } \\
\text { smoker } \\
(\mathrm{n}: 205)\end{array}$ & $\mathbf{p}$ \\
\hline Age & $52.01 \pm 8.93$ & $53.11 \pm 9.84$ & $53.60 \pm 8.97$ & 0.58 \\
\hline Gender Female (\%) & $72(24.2)$ & $370(71.7)$ & $44(21.5)$ & 0.001 \\
\hline $\begin{array}{l}\text { Body Mass Index } \\
\left(\mathrm{kg} / \mathrm{m}^{2)}\right.\end{array}$ & $26.84 \pm 4.82$ & $28.15 \pm 4.46$ & $28.27 \pm 4.41$ & 0.001 \\
\hline $\begin{array}{l}\text { Marital status- } \\
\text { married (\%) }\end{array}$ & 274 (91.9) & $426(82.5)$ & $189(92.2)$ & 0.11 \\
\hline \multicolumn{5}{|l|}{ Education } \\
\hline Uneducated (\%) & $21(7.0 \%)$ & $171(33.1 \%)$ & $30(14.6 \%)$ & \multirow{4}{*}{0.001} \\
\hline $\begin{array}{l}\text { Primaryschool } \\
\text { (\%) }\end{array}$ & $100(33.5 \%)$ & $223(45.2 \%)$ & $72(35.1 \%)$ & \\
\hline $\begin{array}{l}\text { Mid-highschool } \\
\text { (\%) }\end{array}$ & $108(36.2 \%)$ & $77(14.9 \%)$ & $57(27.8 \%)$ & \\
\hline University (\%) & $69(23.1 \%)$ & $45(8.7 \%)$ & $46(22.4 \%)$ & \\
\hline \multicolumn{5}{|l|}{ House hold people } \\
\hline$\leq 2$ & $57(19.1 \%)$ & $147(28.5 \%)$ & $77(37.6 \%)$ & \multirow{3}{*}{0.001} \\
\hline 3-5 & $199(66.8 \%)$ & $324(62.8 \%)$ & $103(50.2 \%)$ & \\
\hline$>5$ & $42(14.1 \%)$ & $45(8.7 \%)$ & $25(12.2 \%)$ & \\
\hline \multicolumn{5}{|c|}{ Monthly income per house person } \\
\hline$<300$ TRY & $49(16.4 \%)$ & $65(12.6 \%)$ & $24(11.7 \%)$ & \multirow{4}{*}{0.001} \\
\hline 300-499TRY & $80(26.9 \%)$ & $178(33.8 \%)$ & $38(18.5 \%)$ & \\
\hline 500-999TRY & $108(36.2 \%)$ & $219(42.4 \%)$ & $89(43.4 \%)$ & \\
\hline$\geq 1000 \mathrm{TRY}$ & $61(20.5 \%)$ & 54 (10.5\%) & 54 (26.3\%) & \\
\hline TRY:Turkishcurrency & & & & \\
\hline
\end{tabular}

Moreover, with a previous chronic pulmonary diseases diagnosis were also more commonly active-smoker (Table $\mathbf{2}$ ).

\begin{tabular}{|c|c|c|c|c|}
\hline & $\begin{array}{l}\text { Active- } \\
\text { smoker } \\
(\mathrm{n}: 298)\end{array}$ & $\begin{array}{c}\text { Non-smoker } \\
(\mathrm{n}: 516)\end{array}$ & $\begin{array}{l}\text { Former- } \\
\text { smoker } \\
(\mathrm{n}: 205)\end{array}$ & $\mathrm{p}$ \\
\hline $\begin{array}{l}\text { Cough >3 } \\
\text { months }\end{array}$ & 64 (21.4\%) & 17 (3.3\%) & 21 (10.2\%) & 0.001 \\
\hline $\begin{array}{l}\text { Sputum }>3 \\
\text { months }\end{array}$ & 67 (22.5\%) & $13(2.5 \%)$ & $18(8.8 \%)$ & 0.001 \\
\hline Effort dyspnea & $108(36.2 \%)$ & $160(31.0 \%)$ & 63 (30.7\%) & 0.28 \\
\hline $\begin{array}{l}\text { Effortless } \\
\text { dyspnea }\end{array}$ & $88(29.5 \%)$ & $158(30.6 \%)$ & $57(27.8 \%)$ & 0.78 \\
\hline $\begin{array}{l}\text { Cough+sputum } \\
>3 \text { months }\end{array}$ & 51 (17.1\%) & $6(1.2 \%)$ & $9(4.4 \%)$ & 0.001 \\
\hline $\begin{array}{l}\text { Cough+sputum }+ \\
\text { dyspnea }>3 \\
\text { months }\end{array}$ & 25 (8.4\%) & $3(0.6 \%)$ & $8(3.9 \%)$ & 0.005 \\
\hline $\begin{array}{l}\text { Family history } \\
\text { for chronic } \\
\text { pulmonary } \\
\text { diseases }\end{array}$ & $26(8.7 \%)$ & $30(5.8 \%)$ & $13(6.4 \%)$ & 0.27 \\
\hline
\end{tabular}

Regarding the symptoms of chronic pulmonary diseases, cough and sputum for longer than 3 months was determined in $66(6.4 \%)$ participants ( 45 male, 21 female) while the triad of cough and sputum for longer than 3 months and dyspnea was determined in 36 (3.5\%) participants (25 male, 11 female). Among those participants the ratio of active-smoker was significantly higher (Table 2) (Figure).

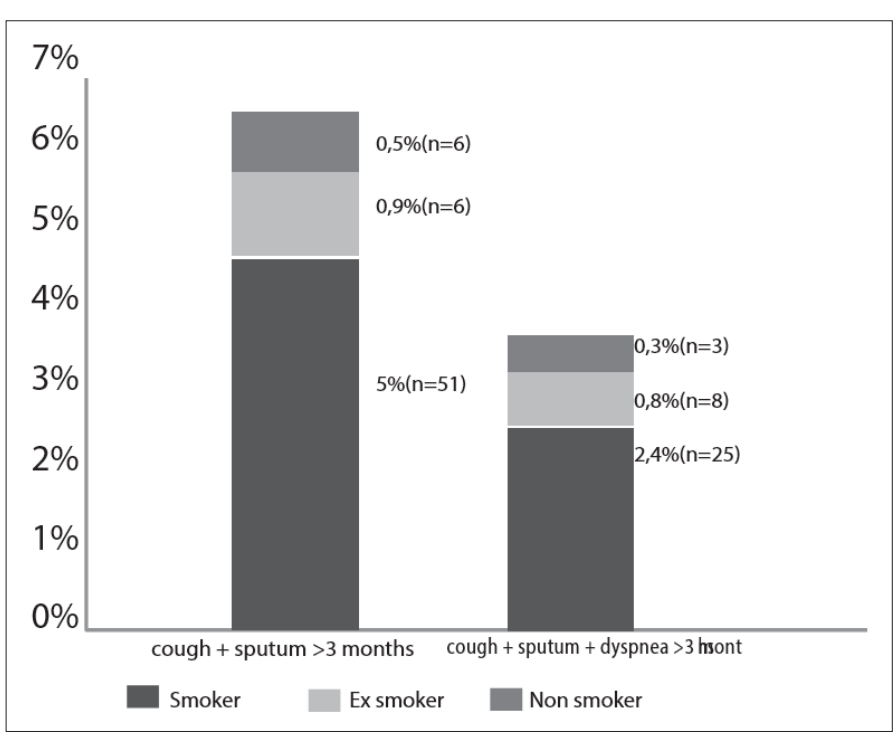

Figure. Chronic respiratory symptoms among study group.

On the other hand, the number of people having symptoms and diagnosis of any chronic lung disease are summarized in Table 3.

Table 3. Patients having symptoms and diagnosis of any chronic lung disease

\begin{tabular}{lccc} 
& $\begin{array}{c}\text { Previous diagnosis of } \\
\text { any chronic pulmonary } \\
\text { diseases (+) }\end{array}$ & $\begin{array}{c}\text { Previous diagnosis } \\
\text { of any chronic } \\
\text { pulmonary } \\
\text { diseases (-) }\end{array}$ & p \\
\hline $\begin{array}{l}\text { Cough+sputum } \\
>3 \text { months }\end{array}$ & $16(24.2 \%)$ & $50(75.8 \%)$ & 0.001 \\
$\begin{array}{l}\text { Cough+sputum+ } \\
\text { dyspnea } \\
>3 \text { months }\end{array}$ & $13(36.1 \%)$ & $23(63.8 \%)$ & 0.001 \\
\hline
\end{tabular}

Regarding these findings, a significant proportion of participants with the symptoms predicting chronic respiratory diseases, were not having diagnosis of any chronic pulmonary disease before.

\section{DISCUSSION}

We investigated the general characteristics of smokers in this study and we determined that in Elazığ, Turkey, about $30 \%$ of randomly selected participants were active-smoker while about $20 \%$ were former-smoker. Males, more educated people, people with higher monthly income and people living with more than 5 people at home were more commonly active-smoker. When the association of respiratory symptoms with smoking status was investigated, cough and sputum presence were associated with the smoking while dyspnea was not associated. On the other hand, the chronic pulmonary diseases predictors cough and sputum for more than 3 months was present in $17.1 \%$ of smokers while cough and sputum for more than 3 months together with dyspnea was present in $8.4 \%$ of smokers. More importantly, we determined 
that, in this group of participants having symptoms, only one third were previously diagnosed with chronic lung disease.

One of the main public health problems associated with smoking is the increased COPD prevalence in smokers. COPD is gaining more importance in recent years with its high mortality and morbidity rates..$^{[9]}$ In a recent study, $90 \%$ of all COPD mortality was associated with smoking. ${ }^{[10]}$ In clinical picture of COPD the main symptoms are cough and sputum which were determined to be significantly more common in smokers. On the other hand it is preventable and treatable but today it is known that COPD is under-diagnosed in the community. ${ }^{[11]}$ The Global Initiative for Obstructive Lung Disease (GOLD) recommends that the diagnosis of COPD should be based on clinical symptoms of chronic bronchitis (cough and sputum production for at least 3 months/year for at least two years) or emphysema (breathlessness and coughing), and/or a history of exposure to risk factors for the disease, confirmed by obstructed airflow measured with spirometry. ${ }^{[12]}$ In that aspect, identifying undiagnosed COPD patients would be beneficial to prevent complications and to improve the life quality of patients. However, very recently screening with the symptomatology was shown to have the modest performance whether assessed individually or in combination since undiagnosed patients were having less severe airflow obstruction and fewer respiratory symptoms compared with diagnosed patients..$^{[13,14]}$ In our study In our study group, approximately $7 \%$ of the participant had chronic respiratory symptoms, but only one quarter of participants with chronic respiratory symptoms were diagnosed with chronic pulmonary disease.

We believe that remaining three forth of the participants should be the target population in chronic pulmonary diseases screenings.

In this study we determined that males, more educated people, people with higher monthly income and people living with more than five people at home were more commonly activesmoker. Although Kim and Cho. ${ }^{[15]}$ reported that married adult males were more successful in cessation of smoking compared with the single people; we did not determine a significant difference regarding the smoking and marital status. This may be due to the high number of married participants in our study. In all 3 groups, most of the participants (>80\%) were married.

In our study, smokers were having significantly lower Body Mass Index (BMI) compared with non-smokers and former smokers. Smoking has been suggested to suppress appetite and increase energy expense, resulting with decreased BMI. ${ }^{[16,17]}$ Similarly, Legleye et al. ${ }^{[18]}$ also reported that smoking was associated with a lower $\mathrm{BMI}$ and smoking cessation with higher BMI in their study on co-twins. In previous studies, smoking was shown to increase along with a decrease in social economic status in especially developed countries. ${ }^{[19,20]}$ However we determined that people with higher monthly income were more commonly smoking. On the other hand, smoking cessation rates in patients with lower socioeconomic status were reported to be lower in developed countries. ${ }^{[21]}$ However, in our study, the percentage of participants who stopped smoking was decreasing with an increase in monthly income.

There are some limitations of this study that should be mentioned. First the data is based on self reports of participants, which may carry some bias. Second, we did not ask for or analyze the effects of second hand tobacco smoke exposure especially at home which may also be an important factor in respiratory symptoms. ${ }^{[22]}$ Third, spirometry was not used to evaluate pulmonary functions. And lastly, we did not record the period of non-smoking among former-smoker or the number of cigarettes smoked per day in current-smokers which may also have some effects on respiratory symptoms.

\section{CONCLUSION}

We determined that; unlike the previous reports, educated and higher monthly income people were more commonly smoker. Regarding these results some new strategies may be created to decrease smoking rates. We also found that chronic pulmonary diseases is not sufficiently diagnosed. In screening for early diagnosis of chronic pulmonary diseases, we think that symptomatic interrogation is still important for selection of target population.

\section{ETHICAL DECLARATIONS}

Ethics Comittee Approval: The study was carried out with the permission of Firat University Non-interventional Research Ethics Committee (2015/08-09).

Informed Consent: Written informed consent was obtained from all participants who participated in this study.

Status of Peer-review: Externally peer-reviewed.

Conflict of Interest Statement: The authors have no conflicts of interest to declare.

Financial Disclosure: The authors declared that this study has received no financial support.

Author Contributions: All of the authors declare that they have all participated in the design, execution, and analysis of the paper, and that they have approved the final version.

\section{REFERENCES}

1. Kõks G, Fischer K, Kõks S. Smoking-related general and causespecific mortality in Estonia. BMC Public Health. 2017;18(1):34.

2. Forey BA, Thornton AJ, Lee PN. Systematic review with metaanalysis of the epidemiological evidence relatingsmoking to COPD, chronic bronchitis and emphysema. BMC Pulm Med. 2011;11:36.

3. Alam DS, Jha P, Ramasundarahettige C, Streatfield PK, Niessen LW, Chowdhury MA, et al. Smoking-attributable mortality in Bangladesh: proportional mortality study. Bull World Health Organ. 2013; 91(10):75764.

4. WHO: MPOWER: a policy package to reverse the tobacco epidemic. In Geneva; 2011[cited 29 Dec 2018] Available from: http://apps.who.int/iris/ 
handle/10665/43888

5. Papadakis S, Cole AG, Reid RD, Coja M, Aitken D, Mullen KA, et al. Increasing Rates of Tobacco Treatment Delivery in Primary Care Practice: Evaluation of the Ottawa Model for Smoking Cessation. Ann Fam Med. 2016;14(3):235-43.

6. Vestbo J, Hurd SS, Agusti AG, Jones PW, Vogelmeier C, Anzueto A, et al. Global strategy for the diagnosis, management, and prevention of chronic obstructive pulmonary disease: GOLD executive summary. Am J Respir Crit Care Med 2013;187(4): 347-65.

7. Medbo A, Melbye H. What role may symptoms play in the diagnosis of airflow limitation? A study in an elderly population. Scand J Prim Health Care 2008; 26(2): 92-8.

8. Stanley AJ, Hasan I, Crockett AJ, van Schayck OC, Zvar NA. COPD Diagnostic Questionnaire (CDQ) for selecting at-risk patients for spirometry: a crosssectional study in Australian general practice. NPJ Prim Care Respir Med 2014; 24(1): 14024.

9. WHO: WHO report on the global tobacco epidemic, 2011: warning about the dangers of tobacco. In. Geneva: World Health Organization; 2011[cited 29 Dec 2018] Available from: https://www.who.int/tobacco/ global_report/2011/en/

10. Pampel F, Legleye S, Goffette C, Piontek D, Kraus L, Khlat M. Cohort changes in educational disparities in smoking: France, Germany and the United States. Soc Sci Med. 2015; 127: 41-50.

11. Gironés Sarrió R, Torregrosa MD, López P, Gómez-Codina J, Rosell R. Smoking habits in elderly lung cancer patients: still no changes in epidemiology? A single-center experience. Clin Transl Oncol 2010;12(10): 686-91.

12. Rabe KF, Hurd S, Anzueto A, Barnes PJ, Buist SA, Calverley P, et al. Global strategy for the diagnosis, management, and prevention of chronic obstructive pulmonary disease: GOLD executive summary. Am J Respir Crit Care Med 2007;176(6): 532-55.

13. Sultana P, Akter S, Rahman MM, Alam MS. Prevalence and Predictors of Current Tobacco Smoking in Bangladesh. J Biostatistics and Biometrics App. 2015;1(1): 1-8

14. Alosaimi FD, Abalhassan M, Alhaddad B, Fallata EO, Alhabbad A, Alshenqiti $\mathrm{R}$, et al. Gender differences and risk factors for smoking among patients with various psychiatric disorders in Saudi Arabia: a cross-sectional study. Int J Ment Health Syst. 2018;12:21

15. Kim Y, Cho WK. Factors Associated with Successful Smoking Cessation in Korean Adult Males: Findings from a National Survey. Iran J Public Health. 2014; 43(11):1486-96.

16. Audrain-McGovern J, Benowitz NL. Cigarette smoking, nicotine, and body weight. Clin Pharmacol Ther $2011 ; 90(1): 164-8$.

17. Munafo MR, Tilling $K$, Ben-Shlomo Y. Smoking status and body mass index: a longitudinal study. Nicotine Tob Res 2009;11(6):765-71.

18. Legleye $S$, Khlat $M$, Beck $F$, Peretti-Watel P. Widening inequalities in smoking initiation and cessation patterns: A cohort and gender analysis in France. Drug Alcohol Depend. 2011;117:233-241.

19. Peretti-Watel P, Seror V, Constance J, Beck F. Poverty as a smoking trap. Int J Drug Policy 2008; 20(3): 230-6.

20. Tashkin DP, Murray RP Smoking cessation in chronic obstructive pulmonary disease. Respir Med 2009; 103(7):963-74.

21. Jha $P$, Ramasundarahettige $C$, Landsman $V$, Rostron $B$, Thun $M$, Anderson $\mathrm{RN}$, et al. 21st-century hazards of smoking and benefits of cessation in the United States. N Engl J Med. 2013; 368(4):341-50.

22. Fell AKM, Svendsen MV, Kim JL, Abrahamsen R, Henneberger PK, Torén K, et al. Exposure to second-hand tobacco smoke and respiratory symptoms in non-smoking adults: cross-sectional data from the general population of Telemark, Norway. BMC Public Health 2018;18(1): 843. 